\section{Influence of Carbon Dioxide in the Calcite-Sodium Oleate Flotation System}

Fatry acids are usually employed in the flotation of carbonate minerals as collectors; among them oleic acid in the form of sodium oleate is important. Mortenson and Ljøkjell ${ }^{1}$ reported that flotation of calcite using sodium oleate as the collector is improved by conditioning the pulp with carbon dioxide. Biswas ${ }^{2}$ pointed out that the improvement due to the use of carbon dioxide is not related solely to the lowering of $p \mathrm{H}$ but is largely attributable to the surface chemical reaction in the system. We report further studies on this system.

To study the calcite-carbon dioxide-water system transparent calcite crystals were wet ground and sieved. About $20 \mathrm{~g}$ of moist samples of $-120+140$ ASTM mesh size range were treated with $150 \mathrm{ml}$. of distilled and deionized water in a $500 \mathrm{ml}$. reagent bottle and then carbon dioxide was bubbled through the system for various times at a constant rate of $3 \mathrm{l} . / \mathrm{min}$. The bottle was shaken for $30 \mathrm{~min}$ and kept in a thermostat (operating at $30 \pm 0 \cdot 1^{\circ} \mathrm{C}$ ) for $\mathrm{l} \mathrm{h}$. For each set, the slurry was filtered and the $\mathrm{Ca}^{++}, \mathrm{CO}_{3}^{-}$and $\mathrm{HCO}_{3}^{-}$concentrations in the filtrate estimated.

Calcium estimation was done by the ammonium purpurate method described by Williams and Moser ${ }^{3}$. The $p H$ was maintained at 11.3 and percentage absorbance was measured at $505 \mathrm{~m} \mu$. It was established that neither carbon dioxide nor sodium oleate interferes with the estimation of calcium by this method. Carbonate and bicarbonate were estimated by titration"; the results are presented in Table 1.

\section{Table 1. GALCITE-CARBON DIOXIDE-WATKR SYSTEM}

\begin{tabular}{|c|c|c|c|c|c|}
\hline $\begin{array}{l}\text { Time of bubb- } \\
\text { ling of carbon } \\
\text { dioxide at the } \\
\text { specifled rate } \\
\text { (min) }\end{array}$ & $\begin{array}{l}\text { Carbonate } \\
\text { (moles/1.) }\end{array}$ & 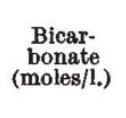 & $\underset{(\mathrm{moles} / 1 .)}{\text { Calcium }}$ & {$\left[\mathrm{Ca}^{++}\right]\left[\mathrm{CO}_{-}^{-}\right]$} & $\begin{array}{c}p \mathbf{H} \text { at the } \\
\text { end of } \\
\text { the } \\
\text { experi- } \\
\text { ment }\end{array}$ \\
\hline $\begin{array}{r}0 \\
5 \\
10 \\
20 \\
\mathbf{3 0}\end{array}$ & $\begin{array}{l}2 \cdot 87 \times 10^{-8} \\
0 \cdot 10 \times 10^{-3} \\
0 \cdot 18 \times 10^{-3} \\
0 \cdot 20 \times 10^{-3} \\
0.13 \times 10^{-3}\end{array}$ & $\begin{array}{l}1.26 \times 10^{-9} \\
1.17 \times 10^{-8} \\
0.16 \times 10^{-3} \\
0.12 \times 10^{-8}\end{array}$ & $\begin{array}{l}0 \cdot 19 \times 10^{-3} \\
1 \cdot 56 \times 10^{-8} \\
2 \cdot 30 \times 10^{-3} \\
3 \cdot 35 \times 10^{-8} \\
3.48 \times 10^{-8}\end{array}$ & $\begin{array}{l}54 \cdot 5 \times 10^{-8} \\
15 \cdot 6 \times 10^{-8} \\
41 \cdot 4 \times 10^{-8} \\
67 \cdot 0 \times 10^{-8} \\
45.2 \times 10^{-8}\end{array}$ & $\begin{array}{l}7 \cdot 26 \\
\frac{-}{5} \\
5 \cdot 56 \\
5 \cdot 80\end{array}$ \\
\hline
\end{tabular}

To study the calcite-carbon dioxide-sodium oleatewater system a similar set of experiments was performed with moist calcite immersed in $100 \mathrm{ml}$. of sodium oleate solution of known concentration and the procedure already described was followed.

In this set of experiments, estimations of sodium oleate and calcium ion were made at different stages. A method of colorimetric estimation of sodium oleate using Nile blue as the complexing reagent was developed on the basis of earlier findings by Goiffin and Conchand ${ }^{5}$. It was necessary to buffer the solution at $p H \mathbf{H} 11 \cdot 2$. Colorimetric estimation at a wavelength of $620 \mathrm{~m} \mu$ was found to be unaffected by the presence of carbon dioxide. Presence of carbon dioxide was found not to interfere with the estimation of sodium oleate. The data obtained are given in Table 2. These results suggest the following.

(a) As more carbon dioxide is bubbled through the calcite suspension, the concentrations of $\mathrm{Ca}^{++}$and $\mathrm{HCO}_{3}^{-}$in the solution increase, presumably as a result of a surface chemical reaction. The equilibrium constant values for the various dissociative reactions in this system were worked out by Garrels and Christ'. According to them, if a calcite suspension is equilibrated with pure water without any gas such as carbon dioxide, the ionic concentration values should be $0.126 \times 10^{-3}, 0.398 \times 10^{-4}$ and $0.891 \times 10^{-4}$ moles/l. for $\mathrm{Ca}^{++}, \mathrm{CO}_{3}^{-}$and $\mathrm{HCO}_{3}^{-}$, respectively. It should be pointed out that, according to Mellor ${ }^{2}$, the solubility of $\mathrm{CaCO}_{3}$ is $0.0014 \mathrm{~g} / 100 \mathrm{ml}$. of water at $25^{\circ} \mathrm{C}$ and thus the concentration of $\mathrm{Ca}^{++}$at equilibrium should be $0.14 \times$ $10^{-s} \mathrm{moles} / \mathrm{l}$. Our data reported in Table $1\left(0.19 \times 10^{-3}\right.$ moles/1.) is slightly higher. Garrels and Christ' further postulated on the basis of equilibrium constants that
Table 2. CALCITE-CARBON DIOXIDE-SODIUM OLEATE-WATER SYSTEM Initial concentration of sodium oleate solution: $9.85 \times 10^{-4}$ moles/l.

Time of bubbling of carbon dioxide at the specifled rate (min) 0 5 10 20 30

Concentration of

calcium (moles/1.) $0.32 \times 10^{-8} 0.66 \times 10^{-3} 1.02 \times 10^{-8} 1.71 \times 10^{-3} 2.49 \times 10^{-3}$ Initial concentration of sodium oleate solution: $2.35 \times 10^{-6}$ moles/l Time of bubbling of carbon dioxide $(\mathrm{min}) \quad$ of oleate (moles/l.) adsorbed (moles/g) $\begin{array}{lll}0 & 1.61 \times 10^{-4} & 0.41 \times 10^{-6} \\ 5 & 0.54 \times 10^{-4} & 1.04 \times 10^{-6}\end{array}$ $\begin{array}{rll}5 & 0.54 \times 10^{-4} & 1.04 \times 10^{-6} \\ 10 & 1.74 \times 10^{-6} & 0.39 \times 10^{-6}\end{array}$

Initial concentration of sodium oleate solution: $4 \cdot 70 \times 10^{-4}$ moles/l. $\begin{array}{lll}0 & 1.13 \times 10^{-4} & 2.20 \times 10^{-6} \\ 5 & 0.52 \times 10^{-4} & 2.72 \times 10^{-6}\end{array}$ $\begin{array}{rll}5 & 0.52 \times 10^{-4} & 2.72 \times 10^{-6} \\ 10 & 0.89 \times 10^{-4} & 2.80 \times 10^{-6}\end{array}$

Initial concentration of sodium oleate solution: $9 \cdot 40 \times 10^{-4}$ moles/l. $\begin{array}{lll}0 & 1.02 \times 10^{-4} & 5.35 \times 10^{-6} \\ 5 & 3.03 \times 10^{-4} & 3.94 \times 10^{-6}\end{array}$

equilibration with atmospheric air containing carbon dioxide (partial pressure $10^{-3.5}$ ) would raise the concentrations of $\mathrm{Ca}^{++}$and $\mathrm{HCO}_{3}^{-}$to $0 \cdot 398 \times 10^{-3}$ and $10^{-3}$ moles $/ 1$., respectively, and lower the carbonate concentration to $0 \cdot 126 \times 10^{-4}$ moles/l. These trends are reflected and established in data presented in Table 1 . The value for the ionic concentration product $\left[\mathrm{Ca}^{++}\right]\left[\mathrm{CO}_{3}^{-}\right]$, however, was not constant in the experimental conditions, and differs widely from the theoretical value: $0.2 \times 10^{-8}$. This inconstancy and discrepancy reflect non-attainment of equilibrium conditions.

(b) Even in the presence of sodium oleate, this surface chemical reaction mentioned is evident. The concentration of calcium in the solution increases as more carbon dioxide passes (Table 2). The slower increase in calcium concentration could be caused by an adsorbed layer of oleate hindering the diffusion of carbon dioxide or by the parallel precipitation reaction which results in the formation of calcium oleate.

(c) Adsorption of sodium oleate on calcite increases with a greater initial concentration of sodium oleate and with the use of a limited amount of carbon dioxide. With more carbon dioxide, however, a process of desorption is initiated.

The difference in the adsorption of oleate on calcite in the carbonated and uncarbonated pulp is pronounced for low concentrations of sodium oleate, for example, $2.35 \times 10^{-4} \mathrm{moles} / \mathrm{l}$. For a high concentration such as $9.4 \times 10^{-4}$ moles/1., adsorption actually decreases with the use of carbon dioxide.

(d) Thus it seems plausible that bubbling a limited amount of carbon dioxide increases the concentration of the calcium in the solution through surface chemical reaction, which in turn induces heightened adsorption of collector (oleate) and increases flotability. The beneficial effect of carbon dioxide (in terms of collector adsorption and flotation) is discernible only at low collector concentration $^{2}$.

We thank the Council of Scientific and Industrial Research, New Delhi, for a scholarship to V. Y. S. K.

V. Y. Sampat Kumar

A. K. Biswas

Department of Metallurgical Engineering,

Indian Institute of Technology,

Kanpur, India.

Received January 30, 1968.

${ }^{1}$ Mortenson, M., and Ljøkjell, D., K. Norske Vidensk Selsk Forhand, 33, 12, $155(1960)$.

' Biswas, A. K., Indian J. Technol., 5, 6, 187 (1967).

Williams, M. B., and Moser, J. H., Anal. Chem., 25, 9, 1414 (1953).

- Caven, R. M., Quantitative Chemical Analysis and Inorganic Preparations, 196 (Blackie and Son, Ltd, London, 1962).

- Goiffn, R., and Conchand, Anal. Biol. Clin., Paris, 11, 327 (1953).

- Garrels, R. M.. and Christ, C. L., Solutions, Minerals and Equilibria, 75 (Harper and Row, New York, 1965).

'Mellor, J. W., Inorganic and Theoretical Chemistry (New Impression), 8, 825 (Longmans Green and Co., Iondon, 1957). 